\title{
A Critical analysis on Service Quality and Customer Retention
}

\author{
${ }^{* 1}$ Mr. Manish Kumar \& ${ }^{2}$ Prof Bobby W. Lyall \\ ${ }^{* 1}$ Research Scholar, Dr. A P J Abdul kalaam Technical University, Lucknow (India) \\ ${ }^{2}$ Professor, Shri Ramswaroop Memorial Group of Professional Studies Lucknow (India)
}

\begin{tabular}{l}
\hline \hline ARTICLE DETAILS \\
\hline $\begin{array}{l}\text { Article History } \\
\text { Published Online: } 05 \text { July } 2018\end{array}$ \\
\hline
\end{tabular}

\section{Keywords}

Customer satisfaction, service Quality, Retention, Gap, Expectation

\section{"Corresponding Author}

Email: manishkumar.kumar213[at]gmail.com

\begin{abstract}
The service industry accept an obviously basic part in the economy of various countries. In today's global competitive environment delivering quality service is considered as an essential strategy for success and survival. Service quality in the management and marketing literature is the extent to which customers' perceptions of service meet and/or exceed their expectations for example as defined by Zeithaml et al. (1990).
\end{abstract}

In this paper, the topic is approached via extensive searches of relevant service quality. In order to generate sound strategy, it is essential to priorities the importance of service quality concepts and the paradigm shift in service quality in which customers are placed as value co-creators to increase customer satisfaction with products/services offered.

\section{Introduction}

The service industry accept an obviously basic part in the economy of various countries. In today's global competitive environment delivering quality service is considered as an essential strategy for success and survival (Parasuraman et al., 1985; Reichheld and Sasser, 1990; Zeithaml et al., 1990). Even the public sector organizations have come under increasing pressure to deliver quality services (Randall and Senior, 1994) and improve efficiencies (Robinson, 2003). Customer needs and expectations are changing when it comes to governmental services and their quality requirements. However, service quality practices in public sector organizations is slow and is further exacerbated by difficulties in measuring outcomes, greater scrutiny from the public and press, a lack of freedom to act in an arbitrary fashion and a requirement for decisions to be based in law (Teicher et al., 2002).

Quality is defined as "fitness for use" (Juran, 1974) in userbased approach and "conformance to requirements" (Crosby, 1979) in manufacturing-based approach. There are four main approaches that identify the definition of quality (Garvin, 1984):

1) The transcendent approach of philosophy

2) The product-based approach of economics

3) The user-based approach of economics, marketing, and operations management

4) The manufacturing-based and value-based approaches of operation management.

According to the transcendent view, quality means "innate excellence." It is a mark of uncompromising standards and high achievement, universally recognizable, and recognized only through experience. In product-based approach, quality is viewed as "a precise and measurable variable" and differences in quality reflect differences in the quantity of some ingredient or attribute so higher quality can only be obtained at higher cost. In user-based approach, quality is compared with the satisfaction. The highest quality means the best satisfaction of consumers' preferences. In manufacturing-based approach, quality is defined as "making it right the first time." It is supply based and concerned with engineering and manufacturing practice. In value-based approach, quality is defined in terms of cost and price. It is perceived as a function of price.

\section{Shaping the Service Quality}

Expectations are a function of market communications, image, word of mouth, and consumer needs and learning, whereas experience is a product of a technical and functional quality, which is filtered through the image.

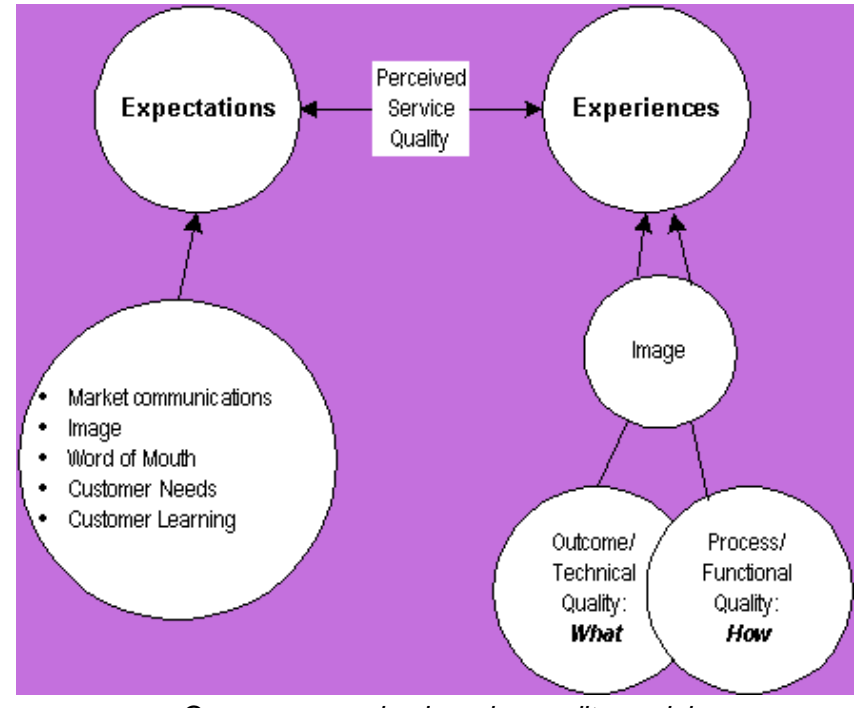

Groonoos perceived service quality model

Grönroos more clearly shows the existence of a perception gap, although there is no suggestion of "delighting" only of narrowing the gap. However the model has more practical application as it shows factors that contribute to each side of the gap. It demonstrates that the supplier can affect both sides of the gap - most notably by managing customer expectations. In addition it illustrates that the customer experience is a product of the image of supplier quality, not just the actuality. Clearly 
marketing as well as process and technical quality has an effect on the perception gap.

\section{Evaluation of service quality}

Generally, there are two different conceptualizations in the service quality literature. As interpreted by Brady and Cronin (2001), the first is from the Nordic perspective, which was developed by Grönroos (1984), who found that the dimensions of service quality in global terms consist of functional and technical quality.

In the Nordic Model, which applies the traditional concept of customer satisfaction/dissatisfaction in explaining service quality. Grönroos (1984, 1998) identified two service quality dimensions, namely technical quality and functional quality. Technical quality focuses on the outcome from the respective service through the interactions with the service provider in satisfying the customer"s basic needs, which indicates the „what" factor (Grönroos, 1984, 1998). Whereas, the functional quality relates to the process dimension, which evaluates the manner of delivery of the respective service from the service provider and it refers to the "how" factor (Grönroos, 1984, 1998). Later, the service quality model was modified to include a third dimension, namely image (Akhtar, 2011; Rahman, Khan \& Haque, 2012).

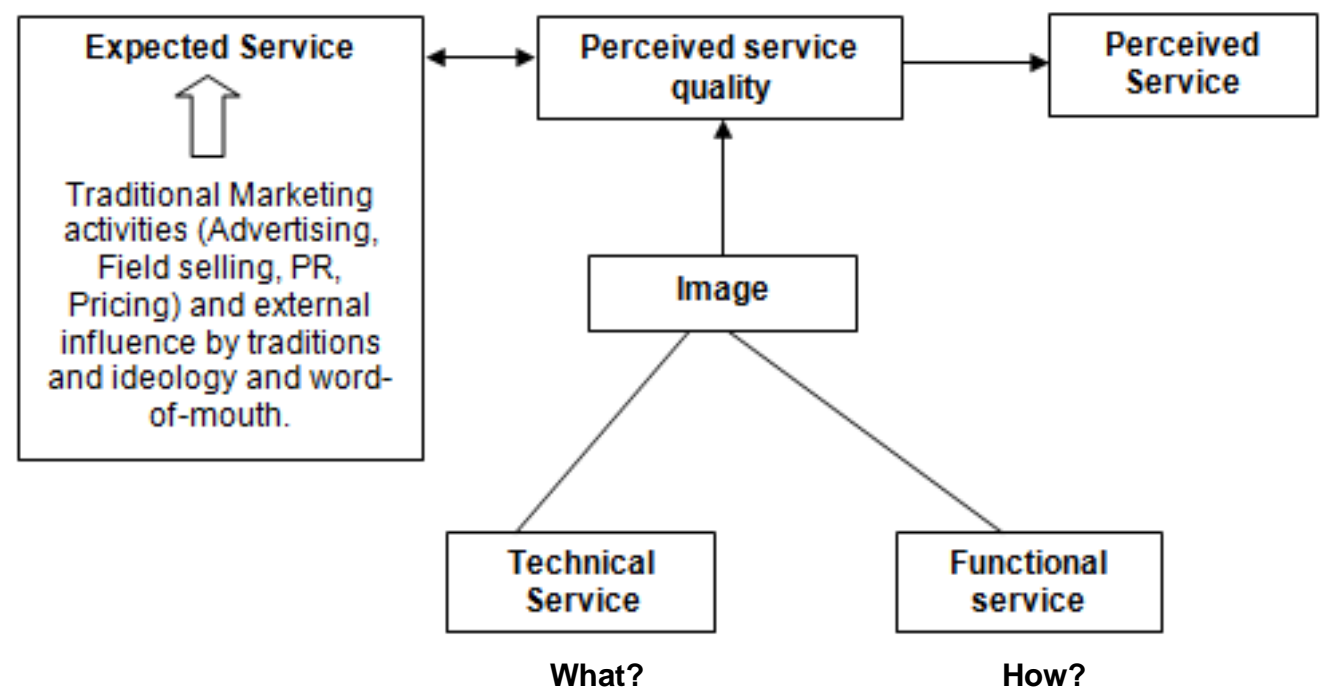

Figure 1: A service quality model and its Marketing Implications-Nordic Model(Groonoos 1984)

The second perspective (Fig. 2)on service quality was developed by Parasuraman, Zeithaml, and Berry (1988) and is called the American perspective (Sayed, 2013). Brady and Cronin (2001) highlighted that Parasuraman et al. (1988) has used terms that describe service encounter characteristics such as reliability, responsiveness, empathy, assurance, and tangibles (Brady \& Cronin, 2001; Sayed, 2013). Parasuraman et al. (1988) developed the concept of expectation and perception of service quality by creating the Gaps Model of Service Quality. They defined the concept by explaining that the Gaps model focuses on the discrepancy between customers" expectation and perception (Parasuraman et al., 1985). The initial model comprised ten dimensions of service quality. These ten dimensions were later reduced to five and the instrument became known as SERVQUAL measurement.

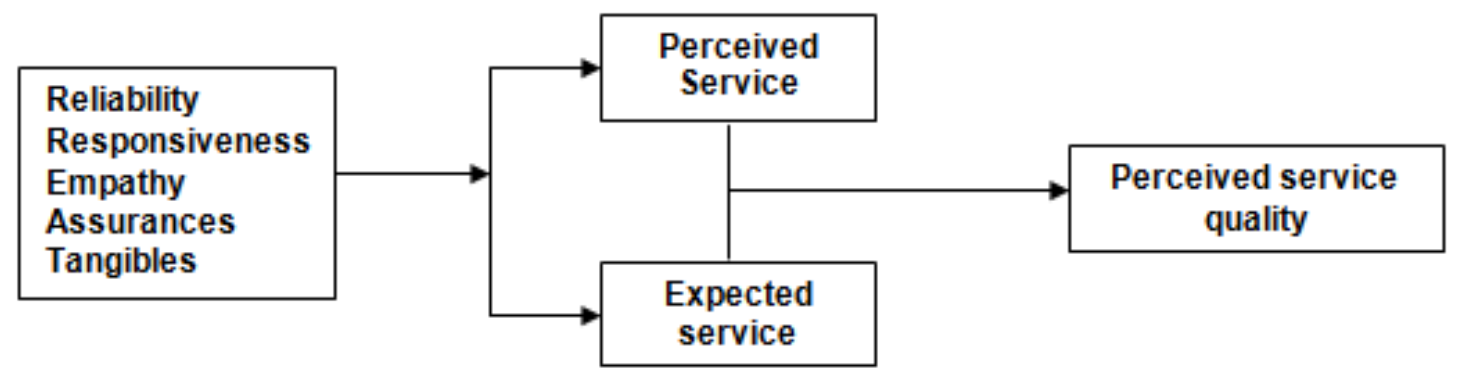

Figure 2: SERVQUAL Model - The American perspective (Parasuraman, Berry, \& Zeithaml, 1985)

\section{Customer Retention}

Customer retention refers to the activities and actions, companies and organizations tries to remove customer defection. The goal of customer retention is to retain as much customer as possible, often through customer loyalty \& brand loyalty initiatives. It starts first by beginning the contact with the customer \& then continuing till entire lifetime of the customer. Overall satisfaction level increases likelihood of returning to the same service.

Customer retention is faster \& costs up to 7 times less than customer acquisition \& this is the reason that it is in trend. In customer retention we do not need to attract, educate \& convert 
new ones \& therefore our expenditure automatically lowers down.

According to Armstrong \& Kotler (2008), they believed that as specific and important relation between corporate and managing performance would influence the organization profit. That customers are assets to hotels and retaining customers in the hotels and retaining customers in the hotel will boost high profits in return. Therefore he continues that good business image in hotels will lead to customer retention and in turn will yield high profits. This is because a hotel having more loyal customers will definitely have many customers and thus increase the hotels revenue

\section{Customer Retention Strategies}

- Clear communication \& messaging helps create engagement and loyal customers.

- Those services which are associated with BRANDS seeks to have more loyal customers.

- Using positive social proofs also help them to getting people listen.

- Tracking of the details of the customers. And therefore make company resemble their "customer".

- Understanding the needs of the customer and therefore positioning our product/service before as well as after.

- Adopting the process of selling that are found to be interesting by customer \& thus creating loyalty.

- Using the words that they love to hear, especially in service marketing.

- Awaking the customer about the products and services that are renovated by the company time to time.

- Not only selling but also educating them about their services \& product.

- Delivering surprise reciprocity and delight.

- But also not overspending on delight.

- Making the product as well as services as much as personal \& special for the customer.

- Speed is always the secondary feature to the quality.

- Customers enjoy businesses who know them.

- Using E-Mails, Messages, and other such networking services to get knowledge about customers and also as constant reminders.

- Get ideal customers to be VIPs.

\section{Literature Review}

The SERVQUAL approach contains a questionnaire that evaluates five generic service dimensions or factors through 22 questions, evaluating both expectation and performance using a seven point Likert scale. This approach evaluates service quality by calculating difference (gap) between customer expectations and perceptions (service quality $=P-E$ ). ' $P$ ' denotes customer perception of service or performance and ' $E$ ' denotes expectations before a service encounter deliver the actual service (Lewis and Booms, 1983; Parasuraman et al.,1985). If the answer is negative, then dissatisfaction occurs, otherwise, the Service Quality is achieved. This equation is usually called gap analysis (Zahari et al., 2008), but as it was emphasized, this approach only measures gap 5 .

\section{Internal service quality model by Frost and Kumar (2000)}

Frost and Kumar (2000) developed an internal service quality model. The model (Figure 2) evaluates the dimensions, and their relationships which determine service quality gaps among internal customers (front-line staff) and internal suppliers (support staff) within a large service organization.

\section{The gaps are as follows:}

Internal gap 1: Difference in support staff's perception (internal supplier) of front-line staff's expectation(internal customers).

Internal gap 2: Difference between service quality specifications and the service actually delivered resulting in an internal service performance gap.

Internal gap 3: Difference between front-line staff's expectations and perceptions of support staff's (internal supplier) service quality. This is the gap which focuses on the front-line staff (internal customers).

Parasuraman et al. (1985) proposed that service quality is a function of the differences between expectation and performance along the quality dimensions. They developed a service quality model based on gap analysis. The gaps include (Seth and Deshmaukh, 2005):

Gap 1: Customer expectation-management gap. This gap addresses the difference between Consumers' expectations and management's perceptions of service quality.

Gap 2: Management perception-service quality specifications gap. This gap addresses the difference between management's perceptions of consumer's expectations and service quality specifications, i.e. improper service-quality standards.

Gap 3: Service quality specification-service delivery gap. This gap addresses the difference between service quality specifications and service actually delivered, i.e. the service performance gap.

Gap 4: Service delivery-external communication gap. This gap addresses the difference between service delivery and the communications to consumers about service delivery, i.e. whether promises match delivery.

Gap 5: Expected service-perceived service gap. This gap addresses the difference between consumer's expectation and perceived service. This gap depends on size and direction of the four gaps associated with the delivery of service quality on the marketer's side. 


\section{Gaps Model of Service Quality}

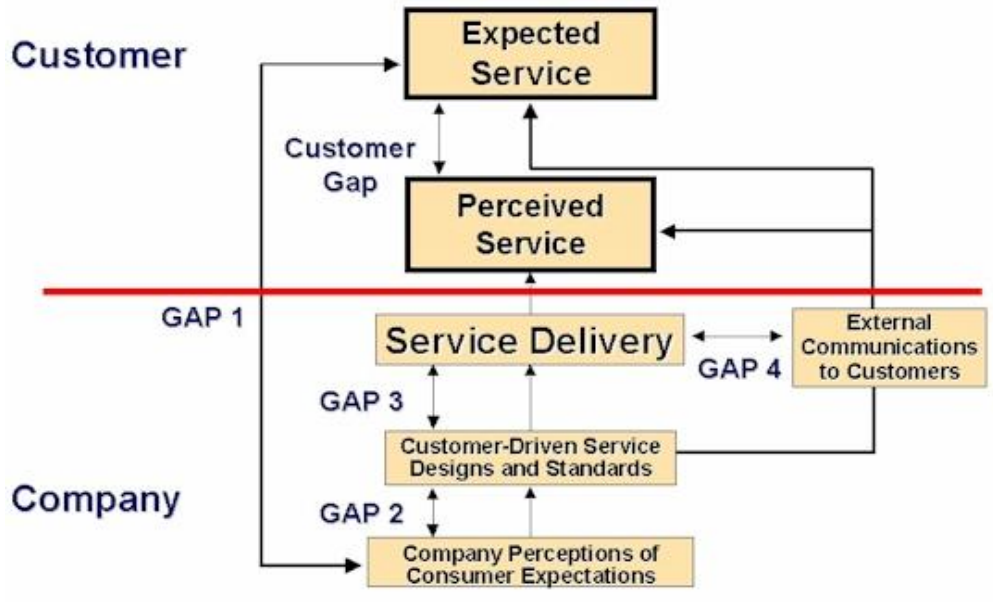

\section{Service Quality Gaps by Luk and Layton (2002)}

Luk and Layton (2002) developed the traditional model of Parasuraman et al. (1998) by adding two more gaps. They reflect the differences in the understanding of consumer expectations by manager and front-line service providers and the differences in consumer expectations and service providers' perception of such expectations.

\section{Critical discussion and development of the models of service quality gaps}

The service quality gaps models can be criticized on both methodological and conceptual grounds (Carman,1990; Cronin and Taylor, 1992; Teas, 1993; Brown et al., 1993).

Cronin and Taylor (1992) proposed that there is a lack of evidence supporting the expectation-performance gap as a predictive measure of service quality. They believe that assessing customer perception is enough for evaluating service quality and it is unnecessary to measure customer expectations in service quality research. They oppose evaluating service quality by calculating the difference between customer perceptions and customer expectations (P-E). Indeed, they define Service Quality as a customer Perception (of Performance only) without expectations. They proposed that the performance based measurement approach (SERVPERF) is more in conformance with the existing attitude and customer satisfaction literature and is superior to the perceptionexpectation gap approach.

Teas (1993) questioned the validity of perceptionexpectation gap with conceptual and operational problem in the definition of the expectation. While perception $(P)$ is definable and measurable in a straight forward manner as the customer belief about service is experienced, expectation $(E)$ is subject to multiple interpretation by different authors/ researchers (e.g. Babakus and Inhofe, 1991; Dabholkar et al., 2000; Gronroose, 1990; Teas, 1993, 1994).

\section{The concept of customer retention}

According to Richards (1996), competition intensifies in the hotel industry; hoteliers shift their strategy from customer acquisition to customer retention and at the same time, information technology continues to make inroads into increasing customer retention and loyalty. Loyalty programmes common to the industry, are important tools for hotels to win and retain customer's loyalty.

\section{Business image}

Loyal customers critically assess the standards of service provided by competing hotel and this confirms that the customers approval of the firm quality of service can outcome into better business image of the hotel industries thus leading to growth in its profits. Richards (1996) states that hospitality industry recognizes that superior quality of service is one of the crucial factors within its control that can add value and amicably will lead into customer retention and loyalty then, good image as well as the quality of service have become the key to hoteliers ability to differentiate itself from its competitors and retain its loyal customers and gain their loyalty.

Gronroos (1994), states that loyalty of firm's customer has been recognized as the dominant factor in a business organizations success. He also indicate that hotel image and customer satisfaction with the performance of housekeeping, reception, food and beverage and price are positively correlated to customer loyalty. Corporate image is influenced both by service quality and customer satisfaction which in turn influences customer loyalty.

Richards (1996), improving business image and retaining customers is done through developing customer loyalty and also depends on food and beverage quality and price. Customers tend to repurchase and recommend a business with a favorable brand image in the belief that it assures high quality goods and services, such as excellent employee attitude and facilities.

Gronroos, (1994), quotes that "hoteliers have to control business image and be able to manage it properly in order for them to retain loyal customer and increase the size of customer. The hotel business images to loyal customers and to the people who can be away become potential customers in the future". 
Kotler \& Keller (2006), states that as hospitality transforms from a traditional and local industry into a global industry, technology becomes more important to customers and improves the business image.

\section{Challenges faced by hoteliers in customer retention in India}

Service Management : Company's growth is measured by various variables like meeting out the various costs, cost of retaining the customers. It is sad to say that companies strive to grow and realize high performance, many organizations find it complex to tackle the dual issues as mentioned above.

Service sync with Market class : One of the major concern is the ability to deliver support services according to customer demands or by increasing the competition. Service/Hospitality industry must develop innovative delivery processes to ensure that they reaching to the maximum potential.

Opportunity to competitors (Bad Service) : Inadequate service does not only create annoyance annoyance to for customers, it will necessarily have a significant impact on a company's business by creating hard feelings among customers on one hand and driving customers into the waiting arms of competitors. Mainly poor customer experience often is the "tipping point" that causes a customer to switch providers.

\section{Discussion}

The above explanation provides a critical discussion of the traditional models, but it is not convincing and it seems that this model still needs to be further developed. In the following, other shortcomings in gaps models are addressed and a model is developed based on the discussion. Considering the critical discussion, more gaps are added to the previous models.

- Ideal service standards;

- Service quality strategy and policy;

- Translation of service quality strategy and policy into service quality specifications and service design;

- Management perceptions of customer perception; and

- Employee perceptions of customer perception.

Service quality strategy and policy is one of the items,. Strategy relates the service organization to its environment and defines the way it wants to compete. Service quality strategy outlines the organization's competitive scope and its concept of quality, through a selection of, and positioning on, the fundamental quality dimensions it wants to compete with (e.g. tangibles and empathy)

Quality dimensions are correlated (Parasuraman at al., 1988, 1993) and, sometimes, an improvement in one maybe achieved only at the expense of another (Garvin, 1987). The challenge is to choose a balanced combination and positioning (Garvin, 1987; Haywood-Farmer, 1988). Highly concentrating on some dimensions may also constitute an appropriate strategy, but may lead to disaster (Haywood-Farmer, 1988).
Finally, service quality strategy is a set of guidelines that provides orientations for everyone in the organization. It should be thoroughly communicated; should be meaningful for personnel; and should distinguish the organization from others. A clearly designed and stated service quality strategy is considered as the starting point at strategy formulation. Indeed, the failure to create a service quality strategy cause in failure to create customer oriented services. It is important for managers to design strategies based on specific customer expectations and their true perception of customer perceptions and expectations.

Failure to forge and communicate a coherent service quality strategy is a serious service quality gap.

Therefore, Gap 2 is defined as "The difference between management perceptions of customer expectations and service quality strategy".

It is important to determine service quality specifications with respect to service strategy dimensions.

Gap 3 refers to the lack of relationship between service quality specifications and service quality strategies. This gap is defined as "The difference between service quality strategy and service quality specifications".

"Ideal standards" is one of the items added into the traditional models. While it is necessary to have a pastexperience from the service, it is not possible to ask a customer (about his/her expectation from the service)who does not have any experience previously. Expectations can also be defined as the ideal standards that customer bears in his/her mind without an experience basis. Therefore, it is decided to add the component of"ideal standards" into the developed model.

Gap 4 addresses how much specifications are far from ideal standards that customer bears in his/her mind. The lack of analysis, design and definition of ideal standards causes this gap. This gap is defined as "The difference between ideal standards and service quality specifications".

In order to set correct specifications, it is important to pay attention to the external communications. In external communications, it is important to use communication means to inform, persuade and educate the customer and also to get the information about some specifications that must be set by organizations to design a customer-oriented service and to have better external communications. Lack of such effort may result in service quality gap. This gap (i.e. Gap 5) is defined as "The difference between external communications and service specifications".

Gap 6 means a management lack of understanding of customers' perceptions of the service, motivated by both lack of initiatives to listen to customers (Zemke and Schaaf, 1989) and by a lack of correct understanding when these initiatives are taken (Parasuraman at al., 1985).

Therefore, Gap 6 is defined as "The difference between customers' perceived service and management perceptions of customer perceptions". As management perception of customer 
expectation influences service strategy, management perception of customer perception also influences service strategy. With concentrating on both customer expectations and perceptions, managers are able to understand customer satisfaction. Consequently, such correct information prevents them to make wrong decisions and choosing inappropriate strategies and policies. If it does not happen, Gap 7 appears and is defined as "The difference between management perceptions of customer perceptions and service strategy"."Employee perceptions of customer perceptions" another component added into the traditional models.

In the traditional model of service quality gaps, Gap 6 is defined as the difference between customer expected service and employee perception of customer expectations, but it is important that employees understand customer perceptions of

\section{References}

1. Crosby, P. B. (1979). Quality is free. New York: New American Library.

2. Garvin, D. A. (1984). What does "product quality" really mean. Sloan management review, 26(1).

3. Parasuraman, A., Zeithaml, V. A. and Berry, L. L. (1985). A conceptual model of service quality and its implications for future research. Journal of Marketing, 49 (4): 41-50.

4. Journal of Marketing Management, Vol. 2(2), June 2014

5. Sweeney, J. C., Soutar, G. N. and Johnson, L. W. (1997). Retail service quality and perceived value: a comparison of two models. Journal of Retailing and Consumer Services, $4(1), 39-48$.

6. http://www.degromoboy.com/cs/gronroos.htm

7. Grönroos, C. (2007). Service Management and Marketing: Customer Management in Service Competition, (3rd ed.). Wiley.

8. International Review of Management and Business Research Vol. 3 Issue.2

9. Brady, M.K. \& Cronin, J.J. (2001). Some New Thoughts on Conceptualizing Perceived Service Quality: A hierarchical Approach. Journal of Marketing, 65(3), 34-50.

10. Syed, T.H., Akhtar, N., \& Khan, N. (2011). Consumer Or Customer - Does The Literature Care For A Difference? Interdisciplinary Journal of Contemporary Research In Business, 2(12), 618-628. service offered. It can result in paying more attention by them in service process in order to achieving customer satisfaction.

Therefore, Gap 8 is defined as "The difference between the customer perceptions and employee perceptions of customer's perceptions". It is important for managers to prepare facilities to improve employee's ability in developing quality relationship with customers and understanding their expectations and perceptions of the service. It makes human resource management (HRM) as the important function in the service industries. HRM involves selection, training, giving adequate levels of autonomy, setting standards/ objectives, accessing individual performance, helping people where help is needed and, finally, rewarding them for their achievements. Selected people are trained to enhance skills, improve attitudes towards customers and learn about the services offered.

11. Customer Retentions in hotels: Emerging trends:AATMBODH

12. Richards, T. (1996). Using the conversion model to optimize customer retention. Managing service quality, 6(4),pp. 48-52.

13. Business Management and Strategy ISSN 2157-6068 2010, Vol. 1, No. 1: E23 www.macrothink.org/bms

14. Frost, F.A. \& Kumar, M. (2000). INTSERVQUAL: an interna adaptation of the GAP model in a large service organization. Journal of Service Marketing, 14(5), 358-377.

15. Luk, Sh.T.K. \& Layton, R. (2002). Perception Gaps in customer expectations: Managers versus service providers and customers. The Service Industries Journal, 22(2), 109128

16. Parasuraman, A., Zeithaml, V.A. \& Berry, L.L. (1985). A conceptual model of service quality and its implications for future research. Journal of Marketing, 49(4), 41-50.

17. Teas, K.R. (1993). Expectations, Performance Evaluation and customer's Perceptions of Quality. Journal of Marketing, 57(9), 18-34.

18. Teas, K.R. (1994). Expectations as a Comparison Standard in Measuring Service Quality. Journal of Marketing, 58(1), 132-139 